\title{
ANÁLISE HISTÓRICA DAS TRANSFORMAÇÕES DA FLORESTA AMAZÔNICA EM ÁREAS AGRÍCOLAS NA BACIA DO RIO SUIA-MIÇU
}

\section{Historical Changes of the Amazonian Forest into Agricultural Lands in the Suia-Miçu River Basin}

\author{
Eduardo Eiji Maeda \\ Mestrando em Sensoriamento Remoto, Instituto Nacional de Pesquisas Espaciais - INPE. eduardo@dsr.inpe.br \\ Antonio Roberto Formaggio \\ Pesquisador Titular - INPE. formag@dsr.inpe.br \\ Yosio Edemir Shimabukuro \\ Pesquisador Titular - INPE. yosio@dsr.inpe.br
}

Artigo recebido para publicação em 10/12/2007 e aceito para publicação em 11/02/2008

RESUMO: $\quad$ Mudanças no uso e cobertura da terra, como as ocorridas nas áreas de expansão agrícola na Amazônia Legal, geram uma série de impactos sociais, econômicos e ambientais. O entendimento destes processos pode permitir um melhor planejamento de políticas públicas a fim de monitorar e mapear áreas mais suscetíveis a problemas ambientais. Sendo assim, este trabalho teve como objetivo analisar a dinâmica de ocupação da Bacia do Rio Suiá-Miçu, um dos afluentes do Rio Xingu localizado ao norte do estado do Mato Grosso. Os mapas de uso e cobertura da terra para cada um dos períodos analisados (1973, 1984 e 2005) foram confeccionados com o auxílio de imagens dos sensores MSS/Landsat-1, TM/Landsat5 e do sensor MODIS/Terra. Os resultados mostraram que até 1984, 13\% da vegetação natural da bacia havia sido desflorestada, enquanto que em 2005 as atividades agrícolas já ocupavam 40\% da área de estudo. Desta forma, tendo em vista as mudanças na paisagem observadas ao longo das últimas décadas, torna-se notória a necessidade urgente de estudos mais aprofundados visando a avaliação dos impactos ambientais, bem como a preservação dos recursos naturais na região.

Palavras-chave: Desflorestamento. Expansão agrícola. Sensoriamento remoto. Amazônia.

ABSTRACT: Land use and land cover changes, as seen in the agricultural expansion areas in the Brazilian Legal Amazon, have as consequence several social, economic and environmental impacts. The understanding of these processes allows a better planning of public policies in order to monitor and map areas more susceptible to environmental problems. Hence, this work had as objective to analyze the land use/land cover changes dynamics in the Suiá-Miçu River Basin, located in the north part of Mato Grosso state, Brazil. The land use/land cover maps for each of the analyzed periods (1973, 1984 and 2005) were made using images from the MSS/Landsat-1, TM/Landsat-5 and the MODIS/Terra sensors. The results showed that until 1984, 13\% of the natural vegetation of the watershed was deforested, while in 2005 the agricultural areas increased to around $40 \%$ of the study area. In that manner, the landscape changes observed along the last decades show the urgent need for studies in order to preserve the natural resources of the region. 
Keywords: Deforestation. Agricultural expansion. Remote sensing. Amazon.

\section{INTRODUÇÃO}

A ocupação da Floresta Amazônica por empresas madeireiras e pela expansão das atividades agropecuárias é atualmente um dos maiores problemas encontrados nesse bioma florestal brasileiro. Esse processo teve início a partir da década de 1970, quando o Governo Federal iniciou uma série de medidas a fim de ocupar e promover o desenvolvimento da região norte do país. Dentre estas medidas pode-se citar a construção de redes rodoviárias, como as rodovias Cuiabá-Santarém e a Transamazônica, incentivos fiscais a fim de estimular os fluxos migratórios e a desapropriação de terras devolutas para projetos agropecuários (ALVES, 2002).

Esses fatores, seguidos pelo domínio de novas técnicas agrícolas que permitiram o cultivo de grão na região, acarretaram o início da chamada expansão da fronteira agrícola. Apesar dos impactos positivos deste processo na economia do país, que transformou o Brasil em uma potência exportadora de produtos agrícolas, esta expansão foi responsável pelo desflorestamento de grandes áreas da Floresta Amazônica. Trabalhos de monitoramento dos recursos naturais, como o Projeto de Monitoramento da Floresta Amazônica brasileira por Satélite (PRODES), mostram que a área desflorestada passou de cerca de 10 milhões de hectares na década de 1970 (TARDIN et al., 1980), para 66,6 milhões de hectares em 2005 (INPE, 2006).

Estudos de modelagem das mudanças do uso e cobertura da terra indicam que, no ano de 2050 , seguindo-se as tendências atuais, cerca de $40 \%$ da Amazônia legal estará desflorestada dando lugar às atividades agropecuárias (SOARES-FILHO, 2006).

Mudanças na cobertura florestal, como as observadas ao longo da Amazônia Brasileira, podem acarretar uma série de conseqüências na biodiversidade, na emissão de gases causadores do efeito estufa e no clima. Um dos processos naturais severamente afetados por estas mudanças é o ciclo hidrológico. A substituição da vegetação original modifica as taxas naturais de evapotranspiração, $o$ que também afeta os padrões locais de precipitação e temperatura. Na região da Floresta Amazônica, por exemplo, aproximadamente metade da água precipitada é proveniente da evapotranspiração da floresta (NOBRE et al., 1991). Estes desequilíbrios trazem também diversas implicações na conservação dos solos e recursos hídricos, uma vez que a retirada da cobertura vegetal original permite um maior carregamento de sedimentos e nutrientes para os córregos e rios, causando uma série de problemas ambientais, como erosão, assoreamento e eutrofização.

Ao longo da história é possível encontrar exemplos em que estes problemas alcançaram proporções catastróficas. No período do império babilônico, as intensas atividades agrícolas ao longo dos rios Tigre e Eufrates causaram a degradação dos solos e a exaustão dos recursos hídricos em algumas regiões da Mesopotâmia. Desta forma, terras antes produtivas transformaram-se em desertos, como pode ser visto ao norte de Bagdá (BERTONI e LOMBARDI NETO, 2005).

O entendimento da dinâmica envolvida nas mudanças do uso e cobertura da terra pode permitir um melhor planejamento de políticas públicas a fim de mapear e monitorar áreas mais suscetíveis a problemas ambientais dando, portanto, suporte para execução de medidas preventivas e remediadoras.

Dentro deste contexto, o presente trabalho teve como objetivo analisar o processo de ocupação da bacia do Rio Suiá-Miçu, localizada na Amazônia Legal em uma região de grande importância cultural e econômica, uma vez que se encontra em uma área de expansão agrícola, e ao mesmo tempo vizinha a diversos Parques Indígenas, como o Parque Indígena do Xingu. 


\section{2. ÁREA DE ESTUDO}

O rio Suiá-Miçu está inserido na bacia Amazônica, sendo um dos afluentes do rio Xingu. Sua bacia está localizada no estado do Mato Grosso, aproximadamente entre as coordenadas $11^{\circ} 15^{\prime} \mathrm{e}$

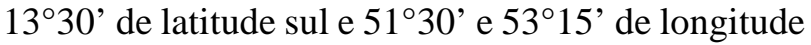
oeste, e sua área de drenagem é de aproximadamente dois milhões de hectares (Figura 1).
A área de estudo abrange parte de seis municípios do estado do Mato Grosso, sendo eles: São Félix do Araguaia, Querência, Alto da Boa Vista, Ribeirão Cascalheira, Canarana e Bom Jesus do Araguaia (Figura 2). A Figura 3 mostra a distribuição percentual dos municípios que compõem a área de estudo, sendo Querência o município com maior área dentro da bacia, compondo aproximadamente 50\% da mesma.

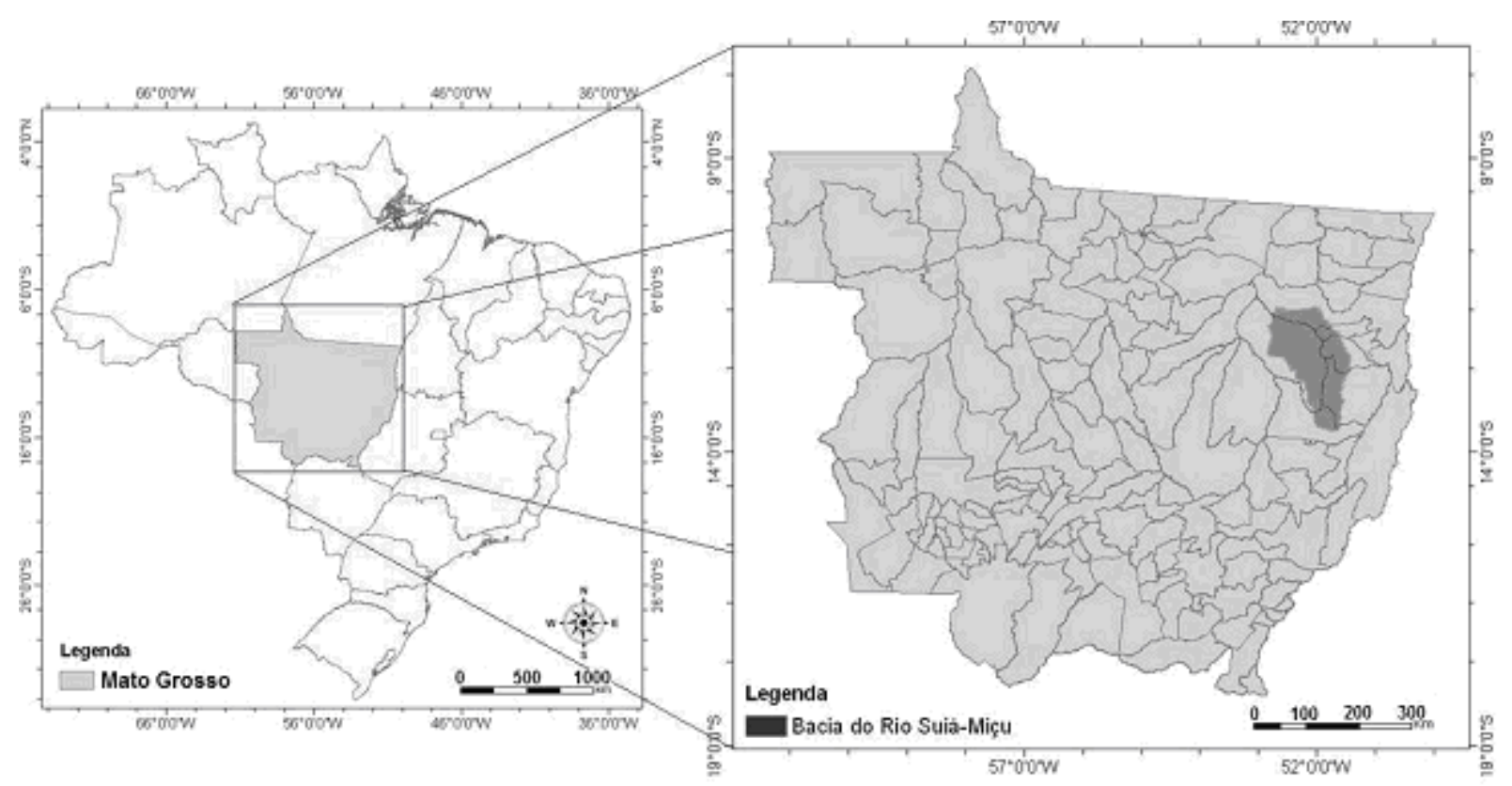

Figura 1. Localização geográfica da área de estudo, a noroeste do estado do Mato Grosso.

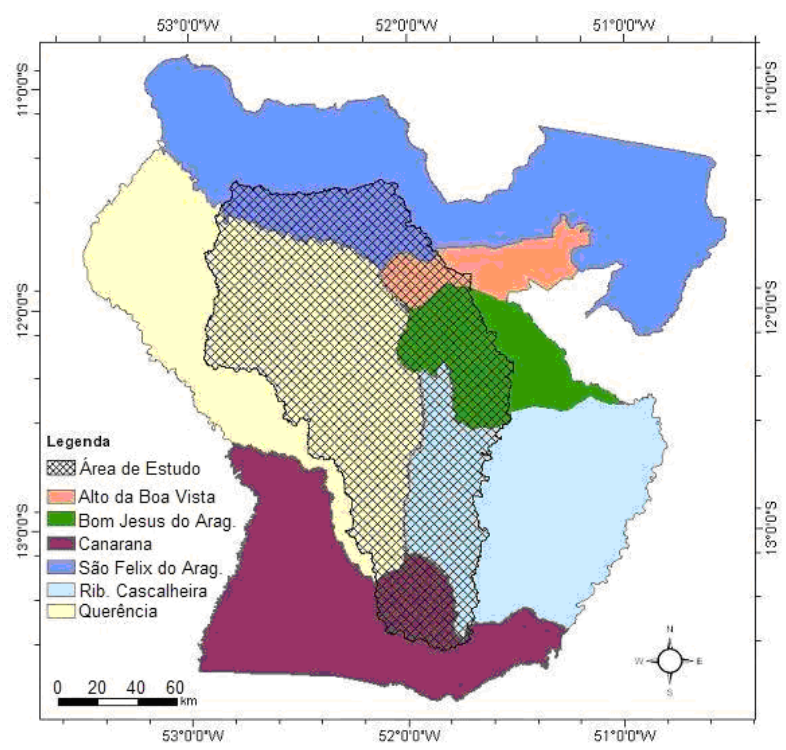

Figura 2. Municípios que compõem a área de estudo. 


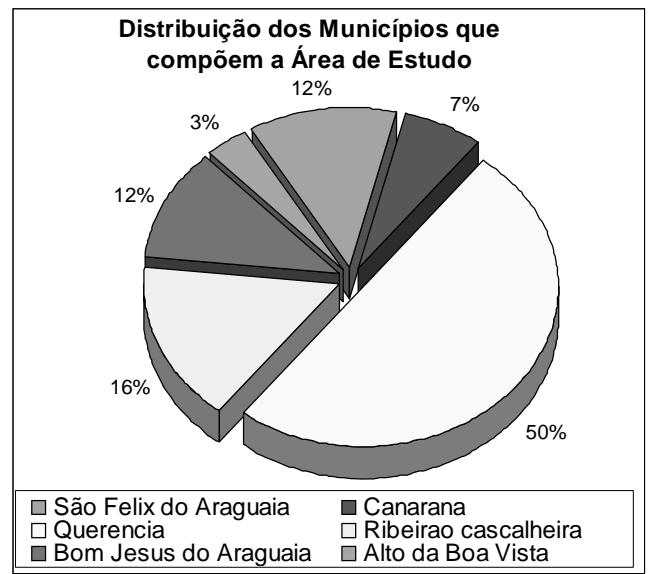

Figura 3. Distribuição percentual dos municípios que compõem a área de estudo.

A economia destes municípios tem base principalmente nas atividades agropecuárias, como a criação extensiva de gado de corte e plantio de culturas temporárias. Em 2005 a área plantada com culturas temporárias nestes municípios somava cerca de $380 \mathrm{mil}$ ha, sendo a maior parte delas encontradas nos municípios de Querência e Canarana (IBGE, 2006).

A vegetação predominante na região compõese de Florestas Estacionais Submontanas, podendo-se encontrar, ao sul da bacia, áreas de Savanas Estacionais Arbóreas. Uma estreita faixa de tensão ecológica entre Savanas e Florestas Estacionais divide estas duas regiões fitoecológicas. As planícies de alagamento dos rios são formadas em grande parte por Florestas
Estacionais Aluviais e Áreas de Formações Pioneiras de Influência Fluvial (SEPLAN, 2001) (Figura 4a).

De uma forma geral o relevo da área de estudo é plano e pouco acidentado, sendo as maiores declividades encontradas na parte sul da bacia, onde há também uma maior densidade de drenagem. Os tipos de solos predominantes são o Latossolo Vermelho-Escuro e o Latossolo Vermelho-Amarelo, no entanto ao sul da bacia também são encontradas áreas compostas por Cambissolos, Solos Concrecionários Latossólicos e Solos Concrecionários Podzólicos. As planícies de alagamento dos rios são formadas por Plintossolos e Gleis Pouco Húmicos (SEPLAN, 2001) (Figura 4b).
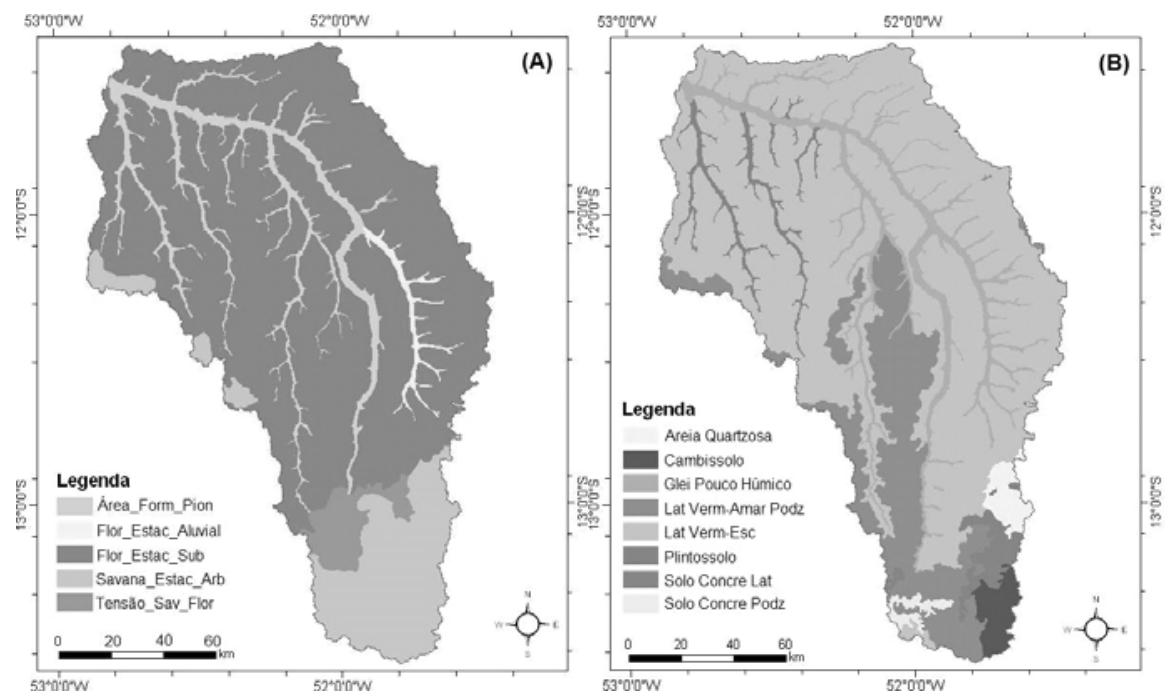

Figura 4. (A) Mapa da vegetação original potencial da área de estudo; (B) Mapa pedológico da área de estudo.

Fonte: SEPLAN (2001); projeto RADAMBRASIL (1981). 
Outro fator que ressalta a importância desta área de estudo é a presença do Parque Indígena do Xingu à jusante do rio Suiá-Miçu (Figura 5). Como pode ser observado na figura, a maior parte da área de drenagem da bacia se encontra fora da área da reserva indígena. Este fato permitiu uma extensa ocupação dos territórios vizinhos à área de preservação, principalmente devido à implantação de atividades agropecuárias. Sendo assim, além da degradação das áreas de nascente do rio Xingu, as atividades agropecuárias podem também trazer problemas para dentro do parque Indígena, decorrentes do carregamento de sedimentos, nutrientes e agrotóxicos.

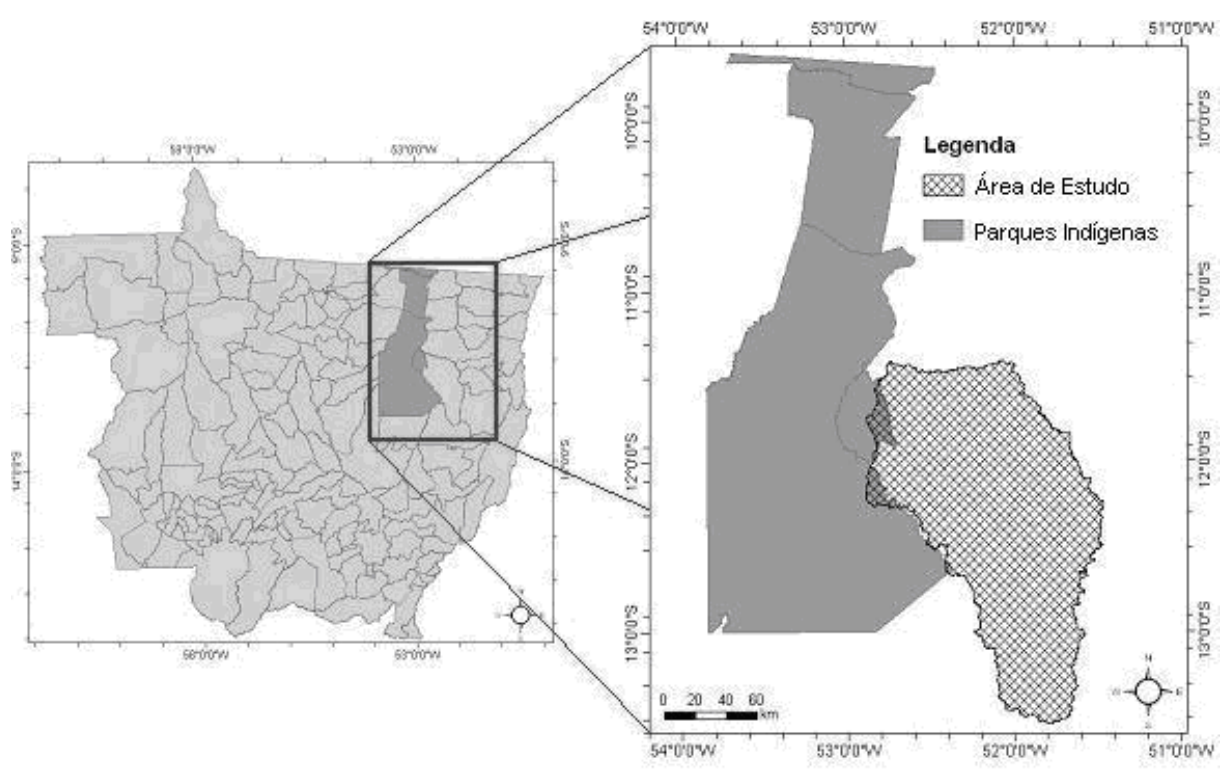

Figura 5. Localização geográfica das áreas indígenas próximas à área de estudo.

\section{METODOLOGIA}

Com a finalidade de estudar a dinâmica de ocupação e das mudanças do uso e cobertura da terra na bacia em foco, três datas foram escolhidas:

I. Ano de 1973, período anterior à fase de ocupação da Amazônia legal;

II. Ano de 1984, período no qual diversos focos de desflorestamento já eram evidentes devido ao início da expansão agrícola;

III. Ano de 2005, período de plena expansão agrícola.

Esse estudo foi feito com base em análises de imagens de sensores ópticos orbitais, cujas características para cada um dos períodos analisados são mostradas na Tabela 1 .

Tabela 1

Dados relativos às imagens orbitais utilizadas neste trabalho.

\begin{tabular}{l|c|c|c|c|c}
\hline Ano & Sensor & $\begin{array}{c}\mathrm{N}^{\circ} \text { de imagens para } \\
\text { cobrir a área de estudo }\end{array}$ & órbita & ponto & Datas \\
\hline 1973 & MSS/Landsat-1 & 4 & 240 a 241 & 68 a 69 & 04 e 23/08 \\
\hline 1984 & TM/Landsat-5 & 4 & 224 a 225 & 68 a 69 & 22 e $31 / 05$ \\
\hline 2005 & TM/Landsat-5 & 4 & 224 a 225 & 68 a 69 & 13 e 20/08 \\
\hline 2005 & MODIS/Terra & 1 & V 10 & H12 & 13 a 28/08 \\
\hline 2006 & MODIS/Terra & 1 & V10 & H12 & $17 / 01$ a 01/02 \\
\hline
\end{tabular}


A classificação das áreas desflorestadas ao longo da bacia foi feita utilizando-se a mesma metodologia proposta pelo Projeto de Monitoramento da Floresta Amazônica Brasileira por Satélites (PRODES) (INPE, 2006). Isto é, através do modelo linear de mistura espectral (MLME) estima-se a proporção de vegetação, sombra e solo, a partir da coleta de pixels puros que correspondam a estas classes; é então gerada a classificação nãosupervisionada por segmentos - ISOSEG das imagens fração, sendo esse classificador baseado na distância de Mahalanobis como medida de similaridade entre as classes (BINS et al., 1993). Posteriormente são direcionadas as classes geradas por este classificador para as classes temáticas do mapeamento.

Os erros inerentes à classificação automática foram corrigidos em edições vetoriais manuais e interpretação visual. É importante ressaltar que a classificação de cada ano foi feita de forma independente, ou seja, áreas desflorestadas em 1984 e que se regeneraram até 2005 , foram consideradas áreas de floresta em 2005.

Em seguida, as áreas desflorestadas classificadas foram sobrepostas ao mapa de vegetação natural potencial da bacia. Este mapa foi adquirido do Instituto Brasileiro do Meio Ambiente e Recursos Renováveis (IBAMA), pela Internet. Os dados originais do mapa de vegetação são oriundos da digitalização dos dados do projeto RADAMBRASIL (1981). A fim de adequar a escala do mapa de vegetação potencial à escala das imagens classificadas foram realizadas edições vetoriais no mapa tomandose por base as imagens do sensor TM/Landsat-5.

Nos anos de 1973 e 1984 todas as áreas desflorestadas detectadas foram classificadas como pastagem, uma vez que nestes períodos as áreas plantadas com lavouras temporárias na região não eram significativas. Este fato pode ser comprovado pelos dados apresentados nas Figuras 6 e 7 obtidos do Instituto Brasileiro de Geografia e Estatística (IBGE, 2006).

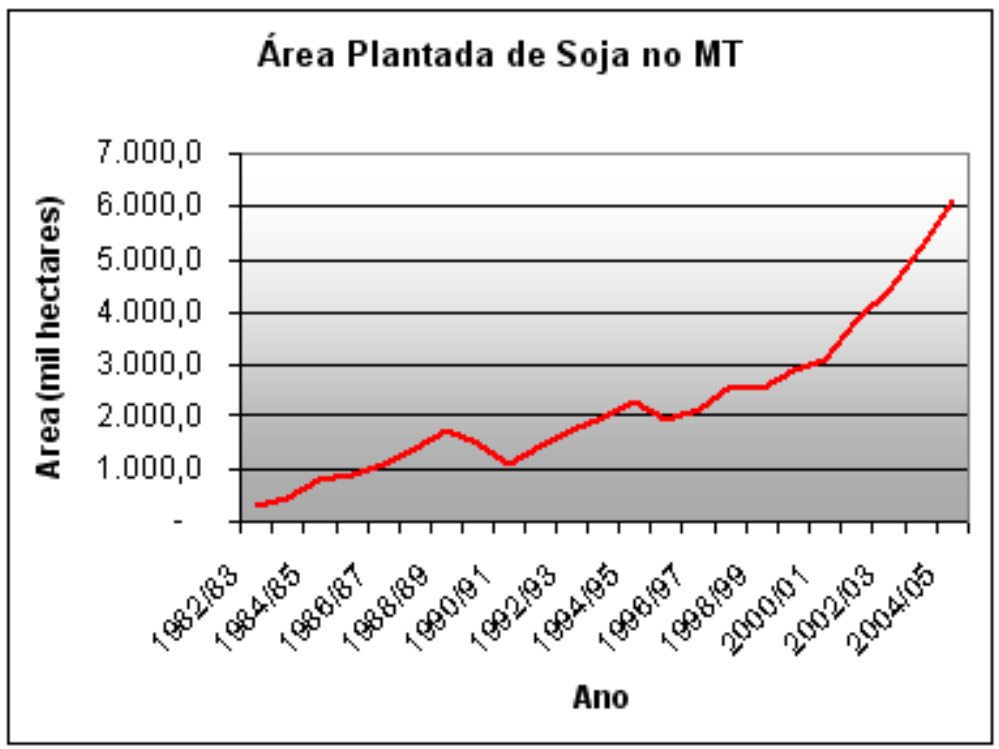

Figura 6. Evolução da área plantada com soja no estado do Mato Grosso.

Fonte: IBGE, 2006 


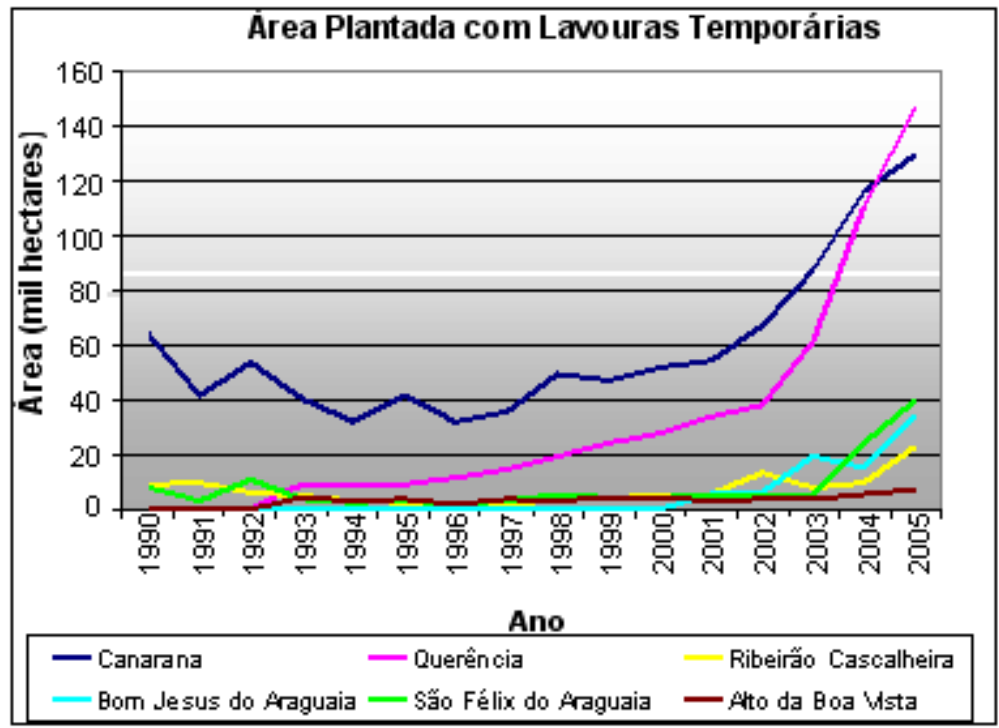

Figura 7. Evolução da área plantada com culturas temporárias nos municípios que compõem a área de estudo.

Fonte: IBGE, 2006

No ano de 2005, as áreas desflorestadas foram classificadas como pastagens ou culturas temporárias. A diferenciação entre estas duas classes foi feita utilizando-se a metodologia proposta por Rizzi et al. (2007), que permite a identificação de culturas temporárias desde que o calendário agrícola das mesmas seja conhecido. Esta metodologia é baseada nos valores mínimos e máximos de EVI (Enhanced Vegetation Index) (HUETE et al., 2002) observados no período de plantio e de máximo vigor das culturas, respectivamente. Estes valores de EVI são então utilizados para o cálculo de outro índice, denominado Crop Enhancement Index (CEI), que é obtido pela equação 1 .

$C E I=\frac{M a x E V I-M i n E V I}{M a x E V I+M i n E V I}$

Onde:

MaxEVI = imagem EVI referente ao período de máximo vigor das culturas;

MinEVI = imagem EVI referente ao período de plantio.
Para o cálculo do índice CEI foi utilizado o produto MOD13, que fornece as imagens índice de vegetação NDVI e EVI oriundas do sensor MODIS/ Terra (JUSTICE et al., 2002). Foram escolhidas imagens de agosto de 2005 (período de plantio) e janeiro de 2006 (período de alto vigor das culturas). A classificação resultante deste processo foi então cruzada com a classificação de áreas desflorestadas realizada sobre as imagens TM/Landsat, as quais foram então divididas entre pastagens e culturas temporárias.

\section{RESULTADOS E DISCUSSÃO}

Na Figura 8 são apresentadas as imagens MSS e TM/Landsat que foram utilizadas neste trabalho. Nota-se que a escolha de imagens referentes a períodos de baixa precipitação permitiu a aquisição de imagens totalmente livres de nuvens, e também com um maior contraste entre as áreas de vegetação e as áreas desflorestadas. 

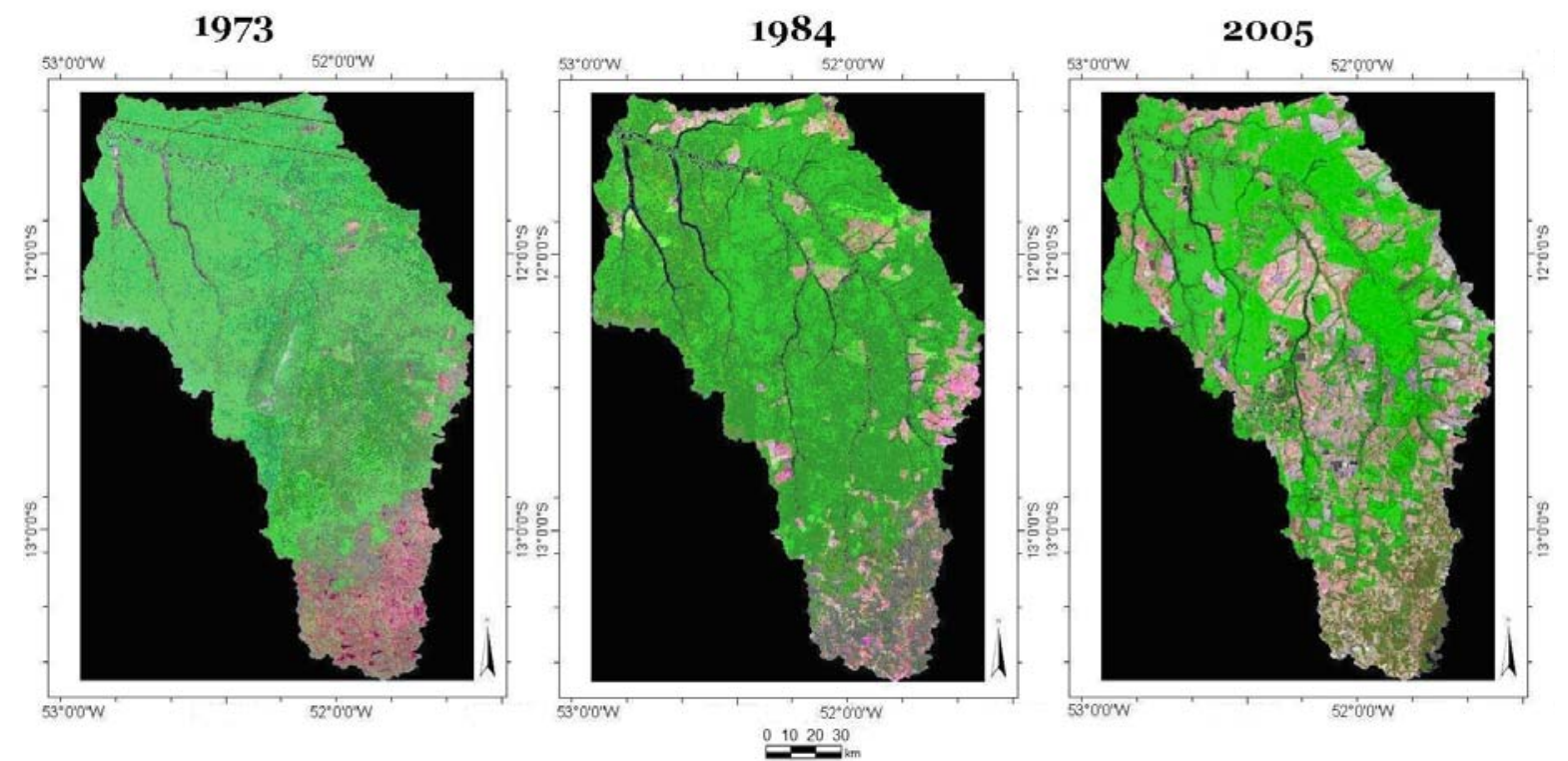

Figura 8. Imagem do sensor MSS/Landsat-1 de agosto de 1973 (esquerda); Imagem do sensor TM/Landsat-5 de junho de 1984 (centro); Imagem do sensor TM/Landsat-5 de agosto de 2005 (esquerda).

Apesar da menor resolução espacial das imagens adquiridas pelo sensor MSS/Landsat-1, essas permitiram uma análise adequada do uso e cobertura da terra para o ano de 1973, sendo a imagem classificada apresentada na Figura 9.

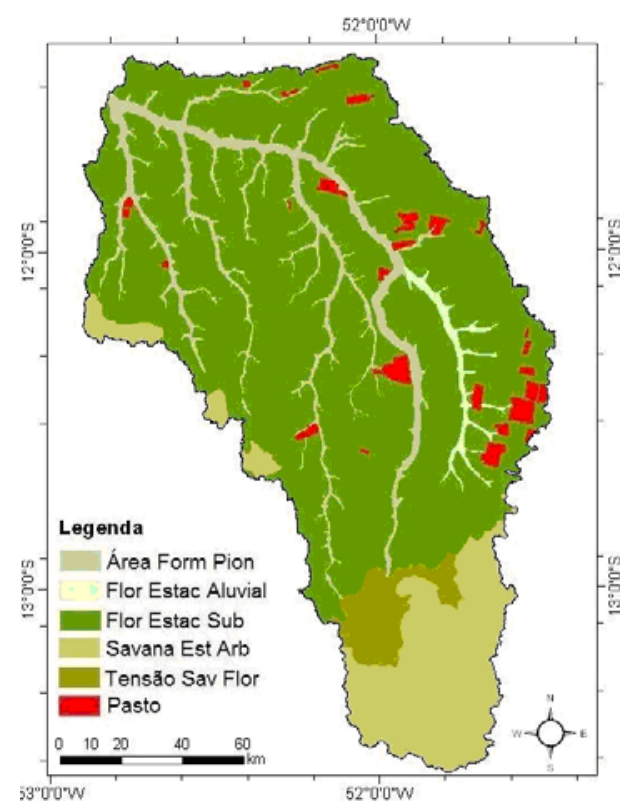

Figura 9. Imagem classificada da área de estudo no período de 1973.

Nota-se que, de forma geral, apenas as áreas de Floresta Estacional Submontana haviam sido desflorestadas até o ano de 1973, sendo as regiões de cerrado e de transição ainda inexploradas. As regiões da bacia pertencentes aos municípios de Bom Jesus do Araguaia e Querência foram as mais desflorestadas, com 176,57 e $151,70 \mathrm{~km}^{2}$ respectivamente. Neste período ainda não eram 
apresentados sinais evidentes de desflorestamento na região da bacia pertencente ao município de Canarana (Figura10a).

No entanto, quando estes valores são

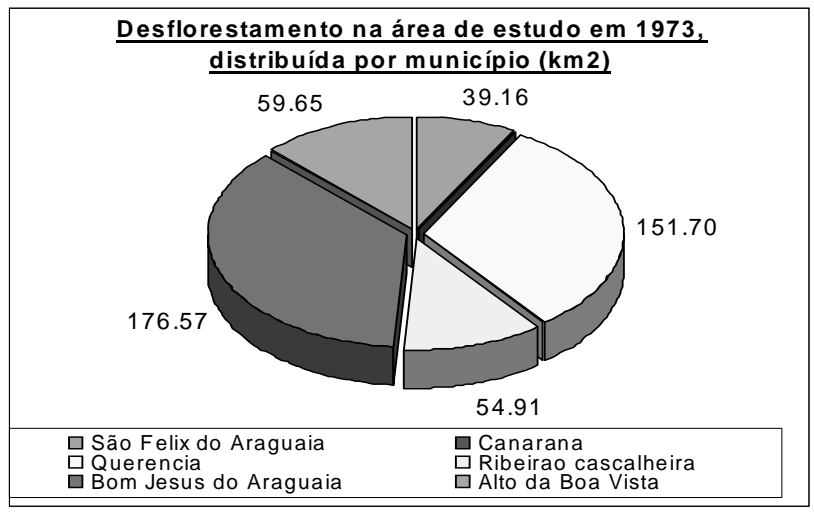

normalizados pela área que os municípios ocupam na bacia, percebe-se que percentualmente os municípios mais desflorestados foram Alto da Boa Vista e São Félix do Araguaia, com 8,12 e 7,22\% respectivamente (Figura 10b).

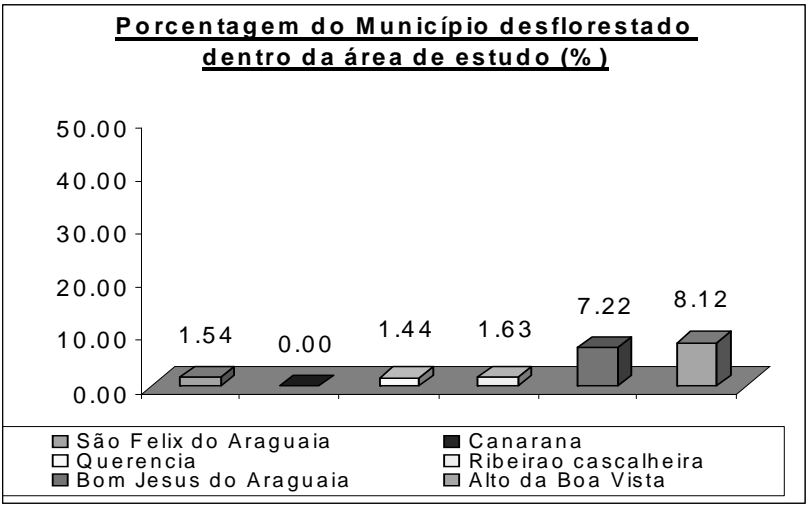

Figura 10. (a) Desflorestamento na Bacia do rio Suiá-Miçu em 1973 distribuído por município;

(b) Porcentagem do Município desflorestado dentro da bacia em 1973.

As áreas de floresta ocupadas neste período tinham como finalidade a exploração madeireira, seguida pela instalação de áreas de pastagens, sendo poucas ou inexistentes as áreas destinadas ao plantio de culturas temporárias.

No ano de 1984, o desflorestamento das Florestas Estacionais Submontanas se expandiu e diversos focos de desflorestamento já eram evidentes nas áreas de cerrado e de tensão ecológica ao sul da bacia (Figura 11). De acordo com os dados do IBGE (2006) mostrados nas Figuras 6 e 7, as áreas plantadas com culturas temporárias não eram significativas neste período, sendo a criação de pastos o destino final da totalidade das áreas desflorestadas neste período.

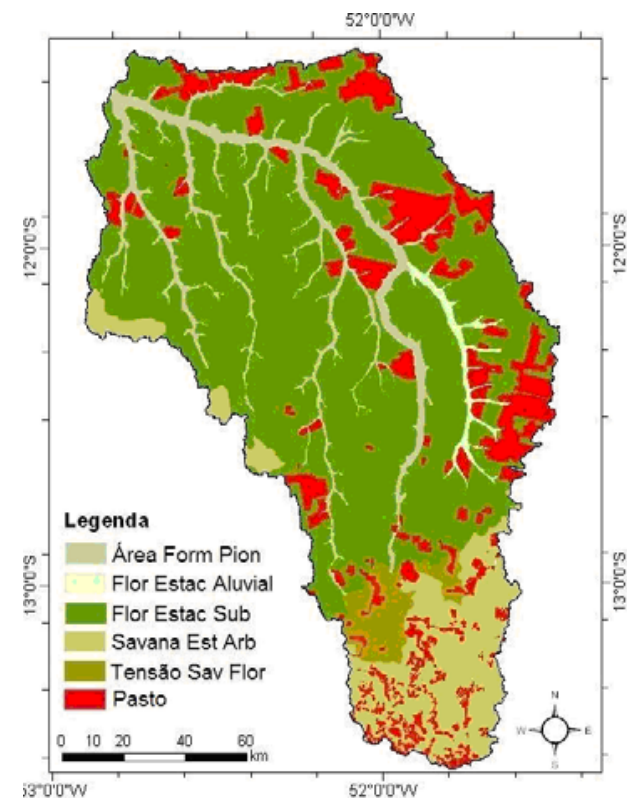

Figura 11. Imagem classificada da área de estudo no período de 1984. 
Uma análise quantitativa mostra que todos os municípios pertencentes à bacia apresentaram aumento nas áreas desflorestadas em 1984 (Figuras 12a e 12b). Querência passou a ser o município com maior área desflorestada dentro da bacia, com $632 \mathrm{~km}^{2}$, no entanto a Figura $12 \mathrm{~b}$ mostra que esta área representava apenas 6\% da região de Querência dentro da bacia.

O município de Canarana, que em 1973 não apresentava áreas desflorestadas dentro da bacia teve, em 1984, aproximadamente $345 \mathrm{~km}^{2}$ de áreas de floresta convertidas para pastagem (Figura 12a).
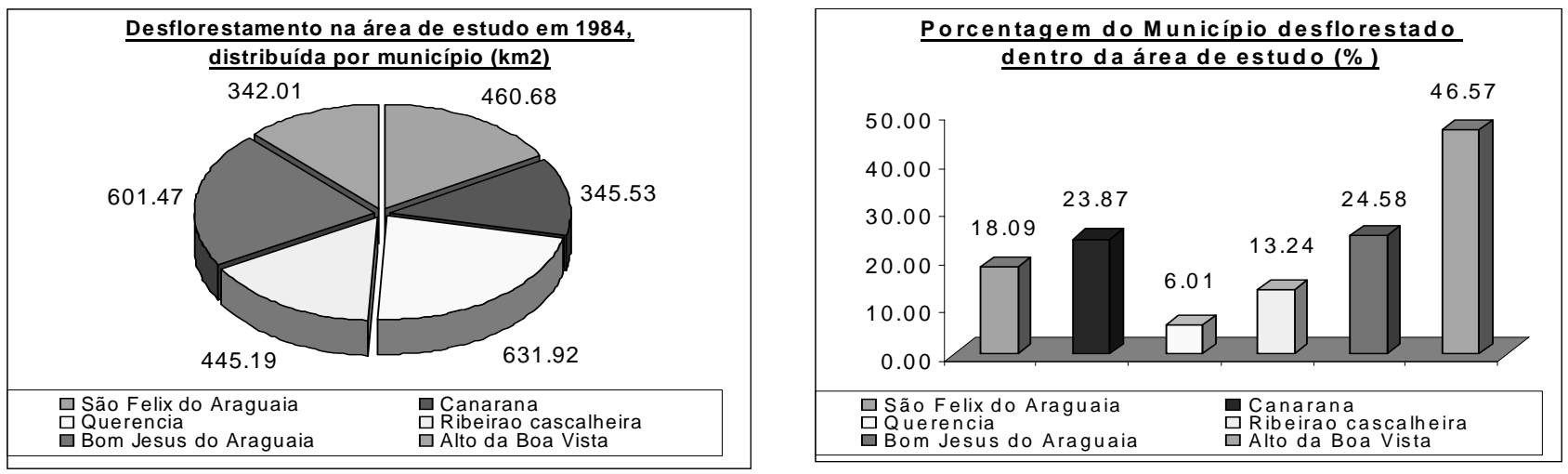

Figura 12. (a) Desflorestamento na Bacia do rio Suiá-Miçu em 1984 distribuído por município;

(b) Porcentagem do município desflorestado dentro da bacia em 1984.

O resultado da classificação das áreas desflorestadas no ano de 2005 é apresentado na Figura13. Neste resultado destaca-se o aumento da exploração da parte central da área de estudo, principalmente nas redondezas da cidade de Querência.

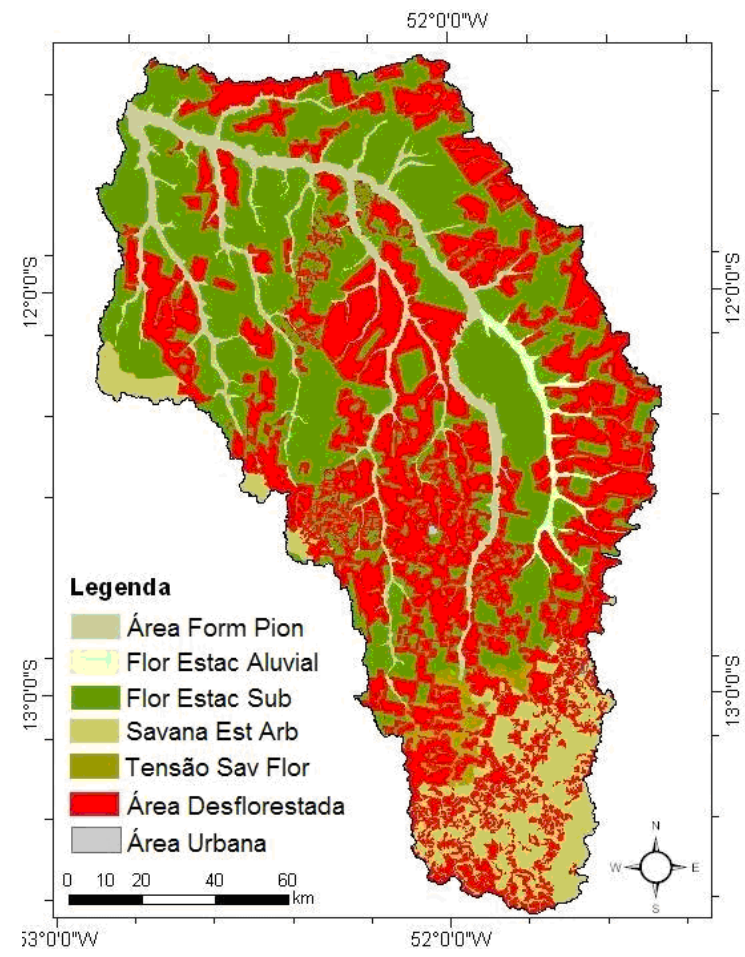

Figura 13. Imagem classificada da área de estudo no período de 2005. 
A intensificação da exploração das áreas ao redor da cidade de Querência fica evidente na Figura 14a, que mostra que a área desflorestada na área de estudo pertencente a este município foi de $4293 \mathrm{~km}^{2}$ em 2005. Isto representa um aumento de aproximadamente $580 \%$ em relação ano de 1984 , quando $632 \mathrm{~km}^{2}$ estavam desflorestados nesta mesma área. Um grande aumento das áreas desflorestadas também pode ser observado na região da área de

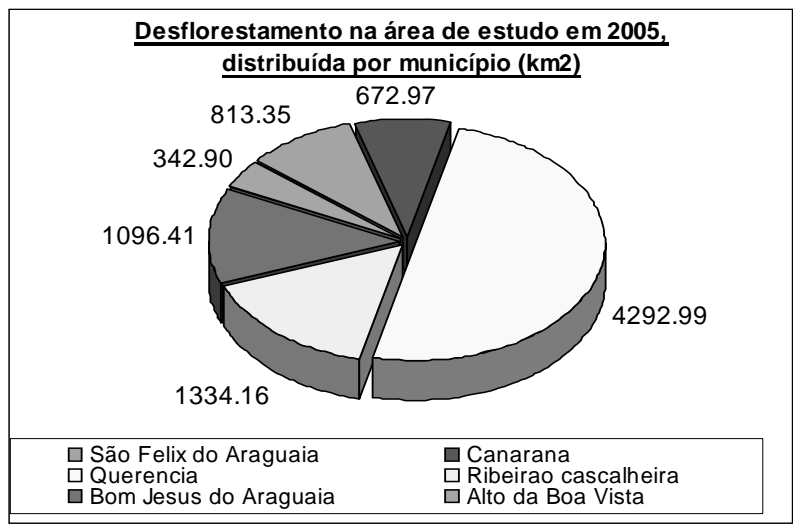

estudo pertencente ao município de Canarana, que passou a ter em 2005 cerca de $46 \%$ de sua vegetação original substituída (Figura14b).

O desflorestamento na região pertencente ao município de Alto da Boa Vista permaneceu constante em relação a 1984, no entanto, como mostra a Figura 14b, esta área desflorestada abrangia mais de $46 \%$ da área do município na bacia.

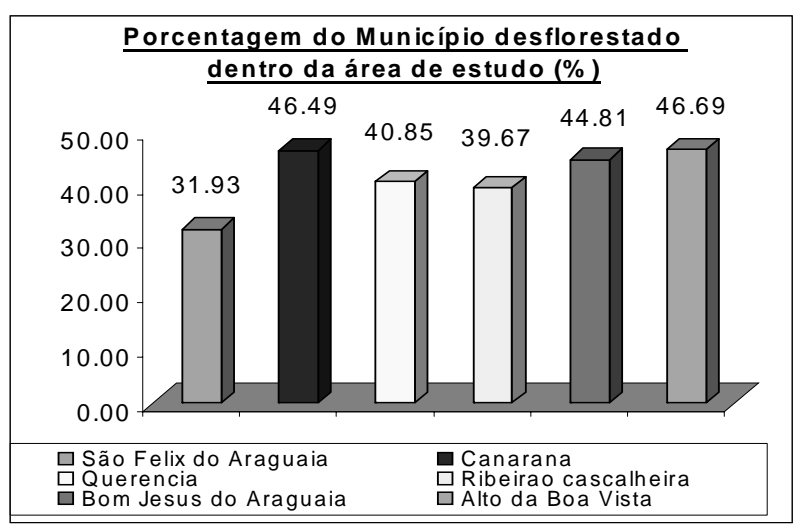

Figura 14. (a) Desflorestamento na Bacia do rio Suiá-Miçu em 2005 distribuído por município; (b) Porcentagem do Município desflorestado dentro da bacia em 2005.

Desconsiderando os limites políticos da região e analisando a área de estudo como um todo, os resultados reafirmam o grande avanço no desflorestamento. A área desflorestada passou de cerca de $480 \mathrm{~km}^{2}$ em 1973 para $2850 \mathrm{~km}^{2}$ em 1984.
Em 2005 cerca de $40 \%$ da área de estudo se encontrava desflorestada, ou seja, $8555 \mathrm{~km}^{2}$, o que representa um aumento de aproximadamente $200 \%$ com relação a 1984 e de $1680 \%$ com relação a 1973 (Figuras 15a e 15b).
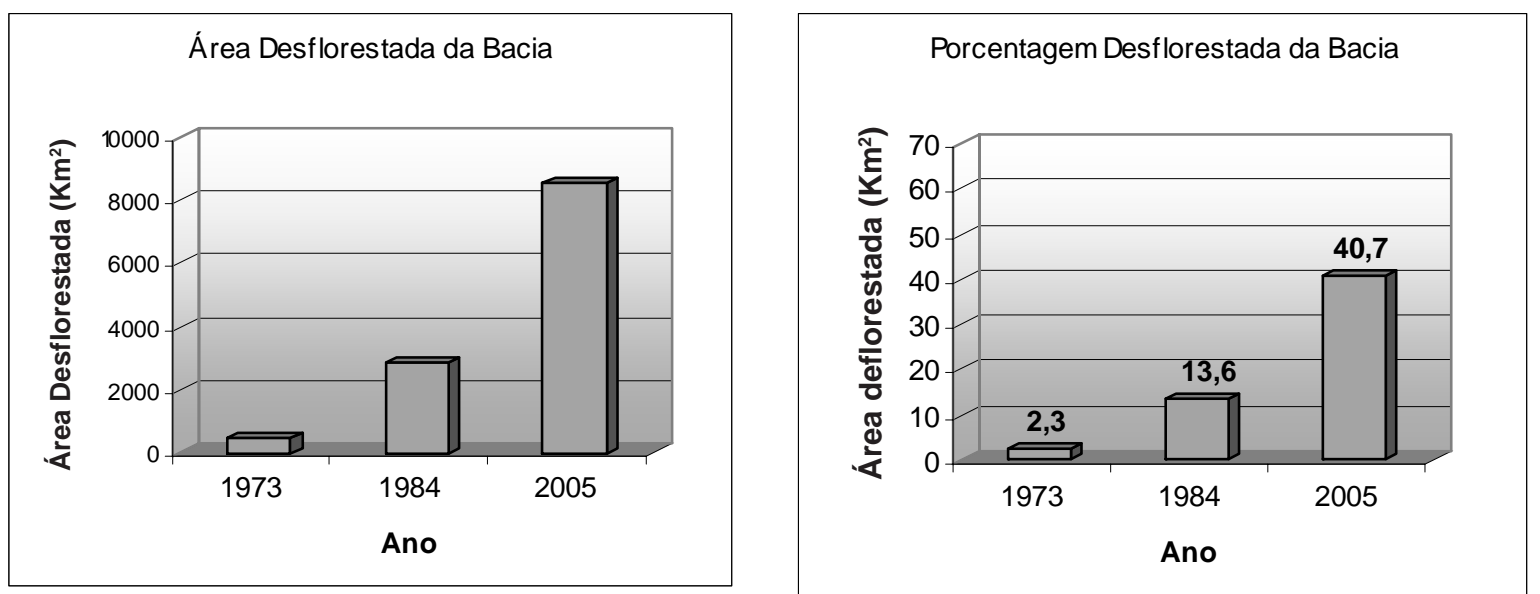

Figura 15. (a) Área total desflorestada na área de estudo, em $\mathrm{km}^{2}$, para todos os períodos analisados; (b) Porcentagem da área de estudo desflorestada em cada um dos períodos analisados. 
As áreas de tensão ecológica, caracterizadas pela transição entre cerrado e Florestas Estacionais Submontana, foram as mais afetadas, restando apenas $42 \%$ da vegetação original em 2005 . As regiões de Florestas Estacionais Submontanas, que ocupam a maior área na bacia, tinham em 2005 apenas 54\% da vegetação original preservada (Figura 16).
As Florestas Estacionais Aluviais e as Áreas de Formações Pioneiras não foram ocupadas de forma significativa. Isto se deve principalmente ao fato de se tratarem de áreas alagadas, e desta forma não propícias ao desenvolvimento de atividades agropecuárias.

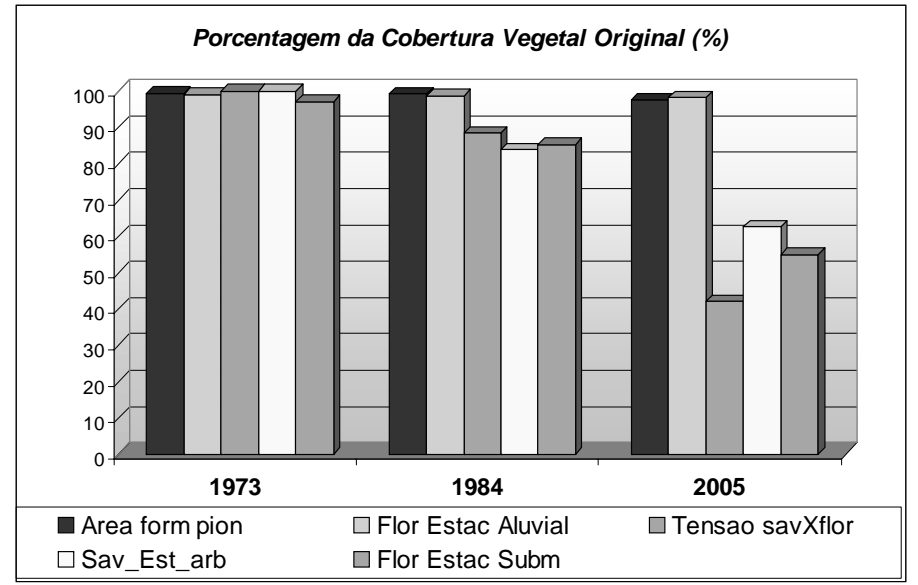

Figura 16. Porcentagem da cobertura vegetal original preservada em cada um dos períodos analisados.

A Figura 17 apresenta um fluxograma que ilustra os resultados obtidos na identificação de áreas plantadas com culturas temporárias no ano de 2005, seguindo a metodologia proposta por Rizzi et al. (2007). As áreas indicadas como sendo de culturas temporárias foram então cruzadas com os resultados obtidos na classificação de áreas desflorestadas para este mesmo período (Figura 16). Desta forma, obtevese o mapeamento final da área de estudo para o ano de 2005, onde as áreas desflorestadas foram separadas entre pasto e culturas temporárias (Figura 18).

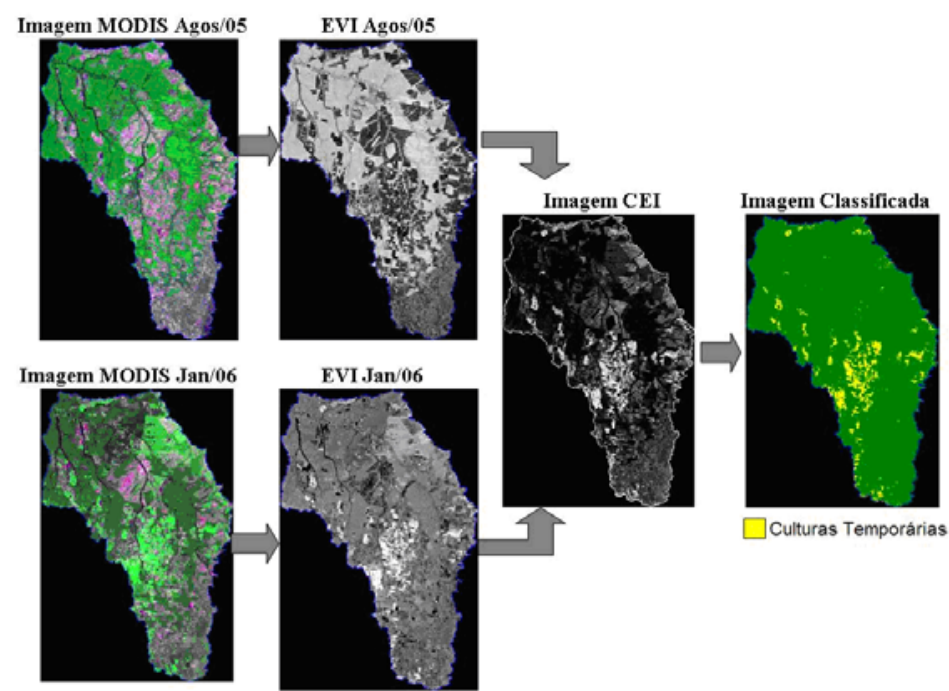

Figura 17. Fluxograma ilustrativo do processo utilizado na identificação das áreas plantadas com culturas temporárias na área de estudo. 


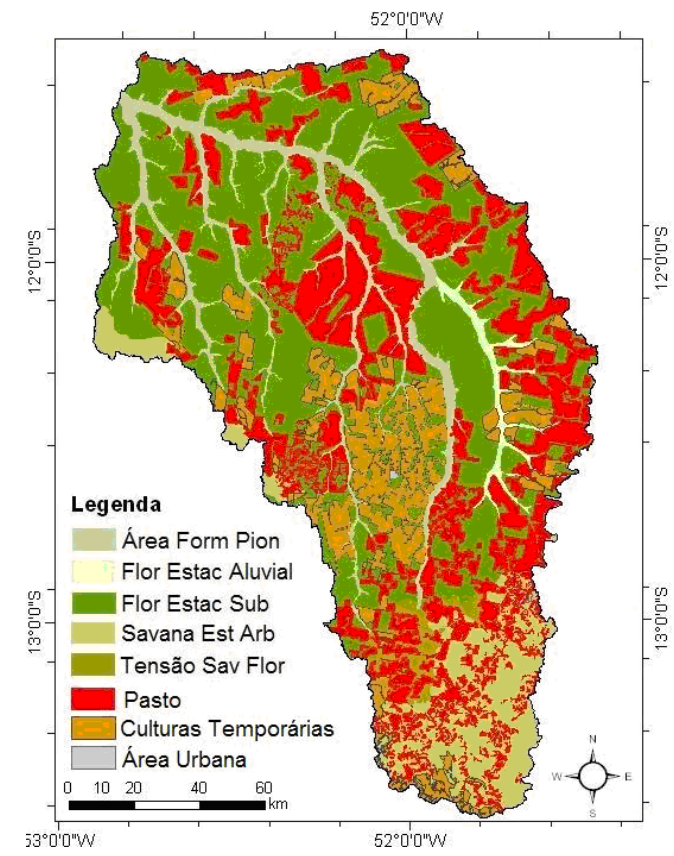

Figura 18. Imagem classificada da área de estudo no período de 2005, onde as áreas desflorestadas foram divididas entre pasto e culturas temporárias.

Os resultados mostram que grande parte do desflorestamento ao redor da cidade de Querência ocorreu em função da expansão de áreas plantadas com culturas temporárias. Este resultado é confirmado pelo gráfico da Figura 7 que mostra um grande aumento das áreas plantadas neste município a partir de 2000.

Além dos fatores econômicos ligados a essa expansão agrícola, o aumento das áreas plantadas nessas regiões pode ser explicado por fatores físicos, como por exemplo, os tipos de solos. A Figura 19 mostra que o plantio de culturas ocorreu quase que em sua totalidade em solos latossólicos. Desta forma, $51,53 \%$ das áreas de cultivo ocorreram sobre Latossolos Vermelho-Escuro, e 46,87\% sobre Latossolos Vermelho-Amarelo Podzólico.

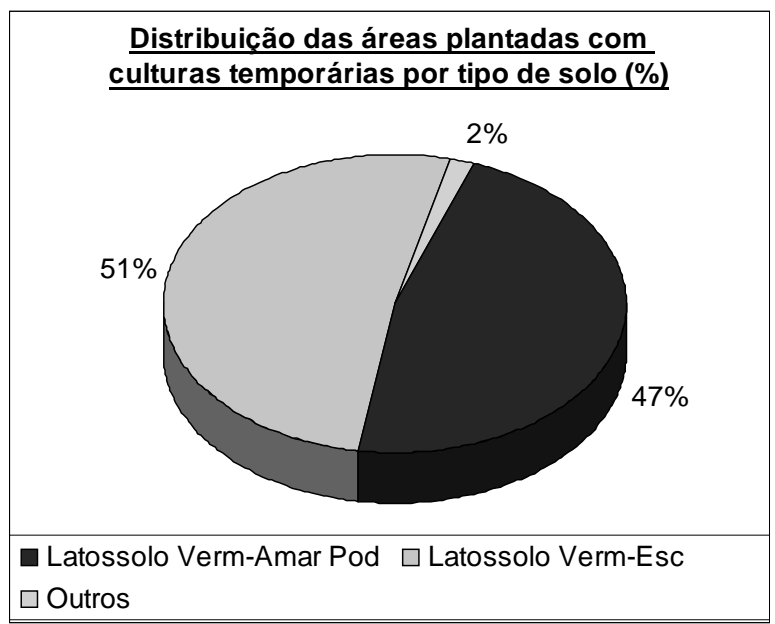

Figura 19. Distribuição das áreas plantadas com culturas temporárias na área de estudo por tipo de solo. 


\subsection{Trabalho de Campo}

Uma visita a campo realizada no período de 15 a 20 de outubro de 2007 permitiu uma melhor visualização das mudanças ocorridas na região, assim como dos problemas ambientais causados em sua decorrência. A rota percorrida ao longo da área de estudo é apresentada na Figura 20.

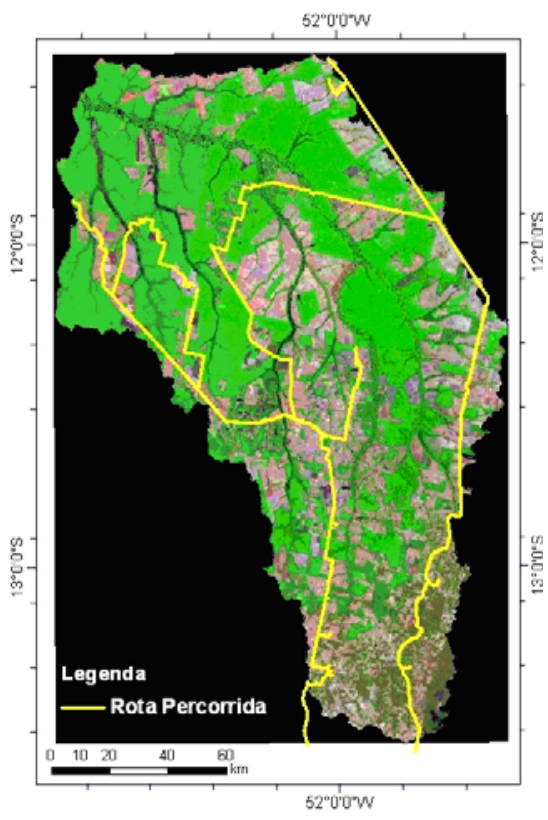

Figura 20. Rota percorrida ao longo da área de estudo durante o trabalho de campo.

A maioria das pastagens localizadas ao sul da bacia não possuem nenhuma prática de conservação, sendo possível encontrar em algumas regiões sedes de fazendas abandonadas (Figura 21). Em algumas

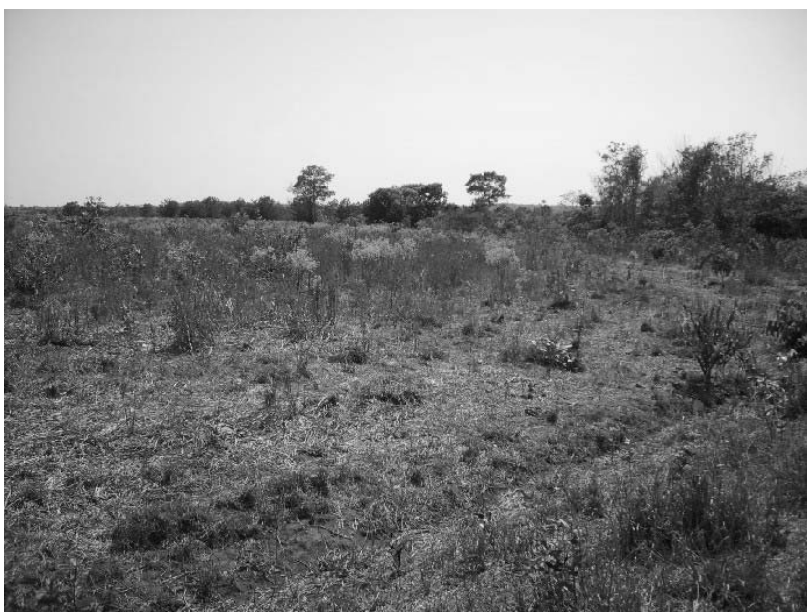

propriedades mais tecnificadas foram observados terraços para acumular a água das chuvas e impedir o avanço do escoamento superficial (Figura 22), entretanto essas são a grande minoria na região.

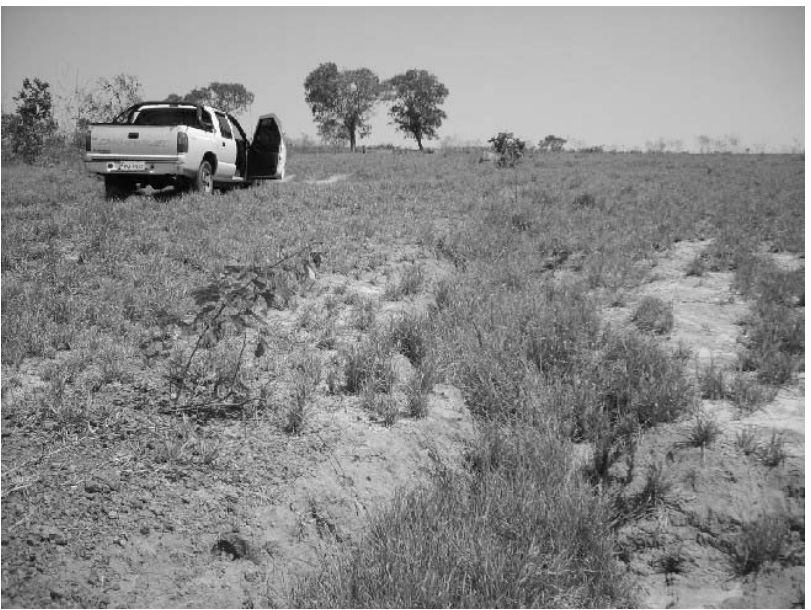

Figura 21. Áreas de pastagem sem conservação localizadas ao sul da área de estudo. 


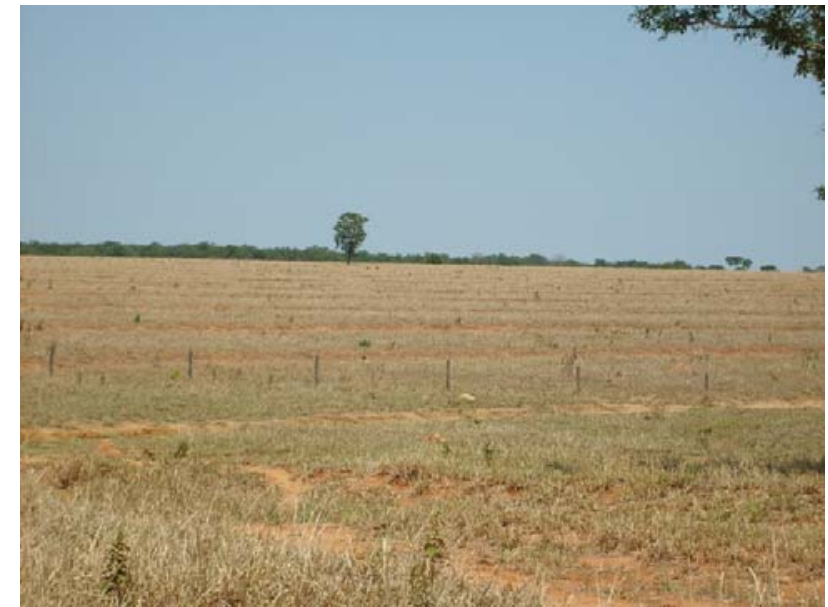

Figura 22. Pastagem ao sul da área de estudo onde podem ser observadas técnicas de contenção do escoamento superficial.

Na região central da bacia, onde se encontram grandes propriedades de produção de grãos, foi observado que, na ocasião do pré-plantio das culturas de verão, os solos são em geral preparados com arados e grades, não sendo utilizada a técnica de plantio direto e nem de cultivo mínimo (Figura 23). Desta forma, a exposição do solo às chuvas, e a total ausência de vegetação indicam um maior desprendimento de sedimento, uma vez que estas áreas eram anteriormente cobertas por florestas densas. A preocupação dos agricultores da região com a construção de terraços e barricadas nas margens das estradas, para contenção do escoamento superficial, indica a ocorrência de um grande carregamento de sedimentos nas épocas de chuva (Figura 24).

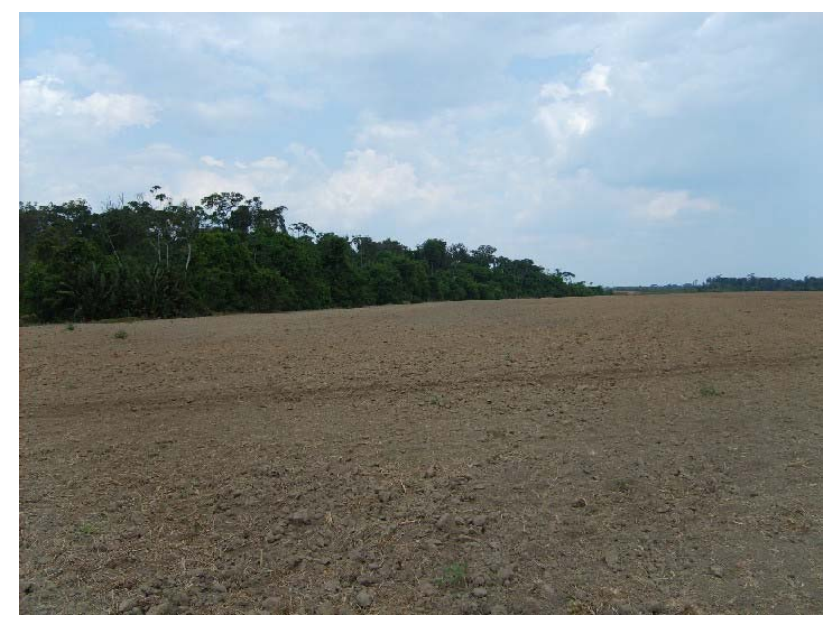

Figura 23. Solos sendo preparados para o plantio de culturas de verão na região central da área de estudo. 

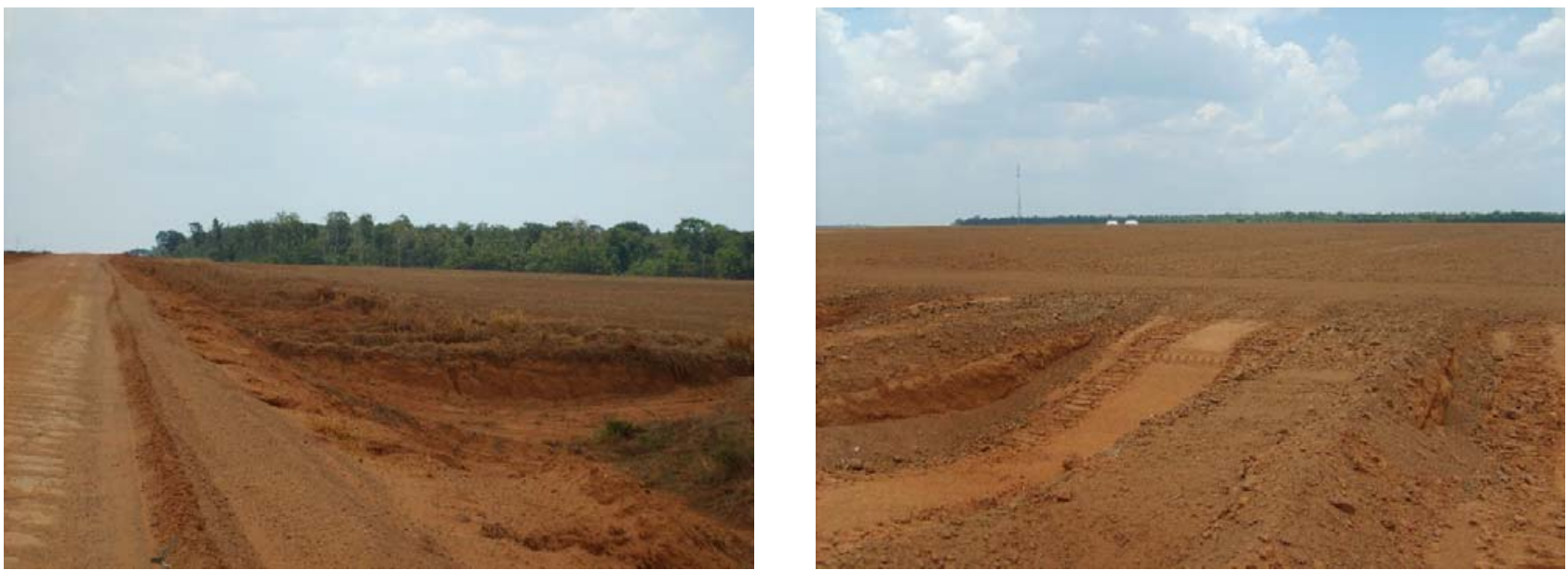

Figura 24. Obras de contensão do escoamento superficial nas margens das estradas na região central da Bacia.

Na região norte, nas proximidades do parque indígena do Xingu, é freqüiente a ocorrência de rios em processo de assoreamento (Figura 25). De forma geral estes problemas são ocasionados pela falta de

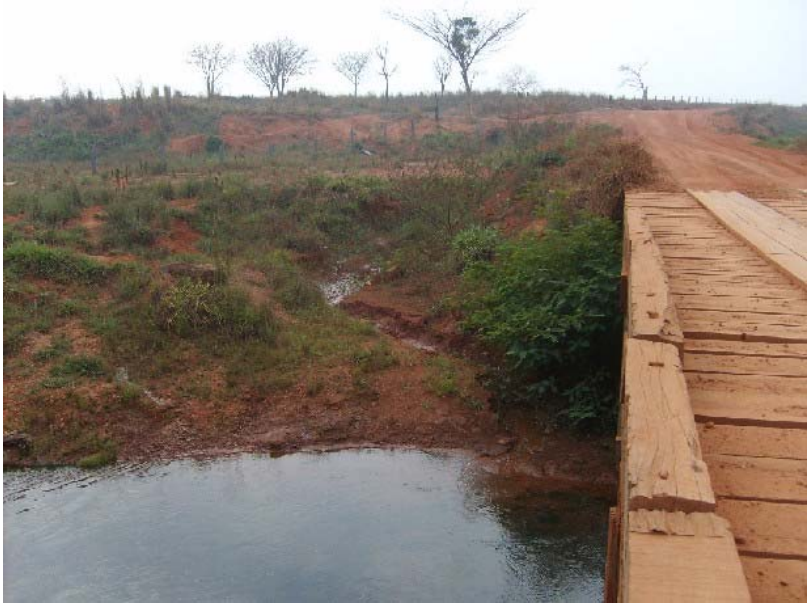

práticas de contenção do escoamento superficial nas estradas, os quais são visivelmente acarretados pelas ações antrópicas na região.

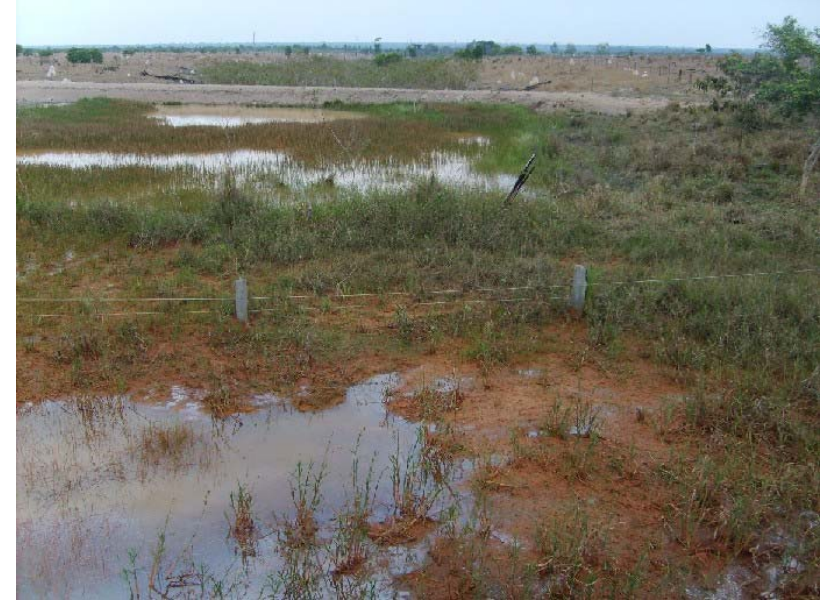

Figura 25. Rios em processo de assoreamento ao norte da área de estudo.

A área de estudo possui duas regiões destinadas a assentamentos. Nestes assentamentos as áreas desflorestadas são predominantemente destinadas à pastagem. $\mathrm{O}$ padrão de desflorestamento nestas regiões difere do restante da bacia, sendo caracterizado por pequenas propriedades, com o limite entre elas mais perceptível (Figura 26). Nenhuma técnica de conservação do solo é utilizada, e a realização de queimadas para eliminação da vegetação original é freqüente (Figura 27). Nestas áreas ainda é possível verificar o grande prejuízo causado ao solo devido à prática de queimadas, além da evidente mudança na proteção do solo. 
Análise histórica das transformações da floresta Amazônica em áreas agrícolas na bacia do rio Suia-miçu Eduardo Eiji Maeda, Antônio Roberto Formaggio, Yosio Edemir Shimabukuro
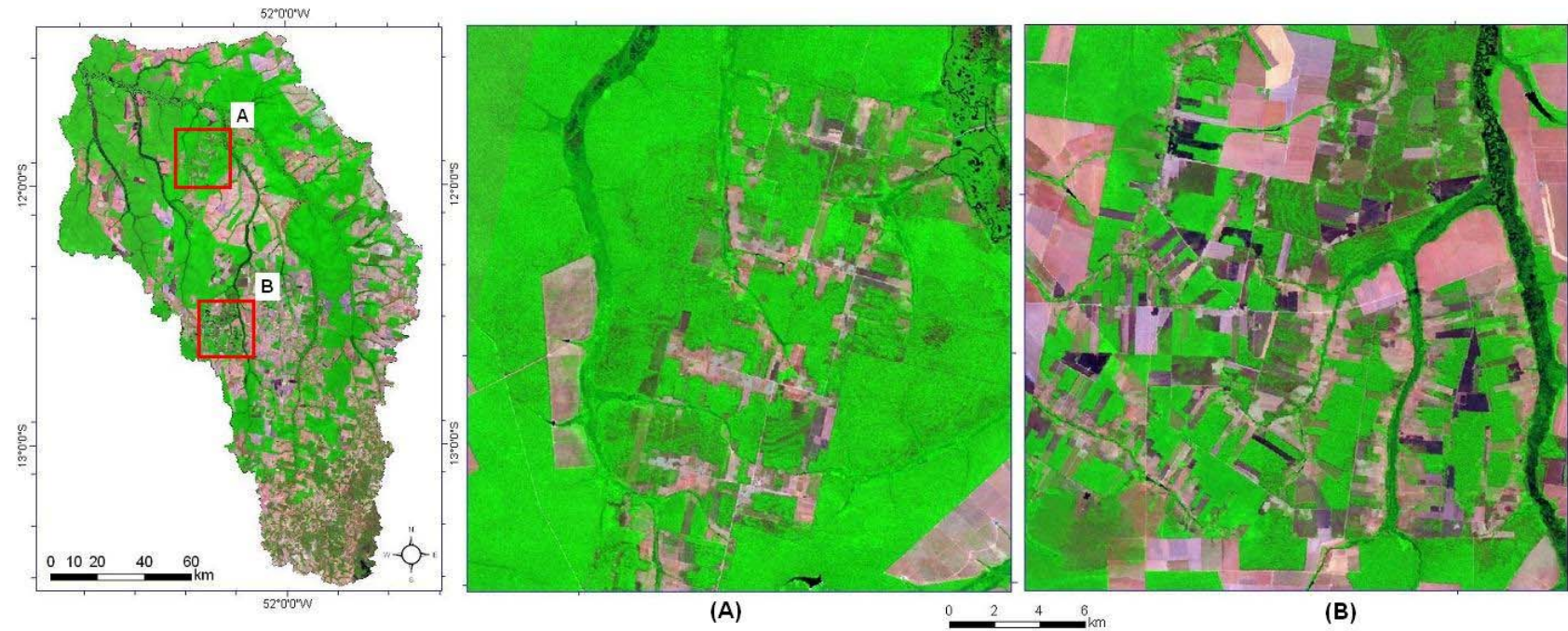

(B)

Figura 26. Localização das áreas de assentamentos (A e B).
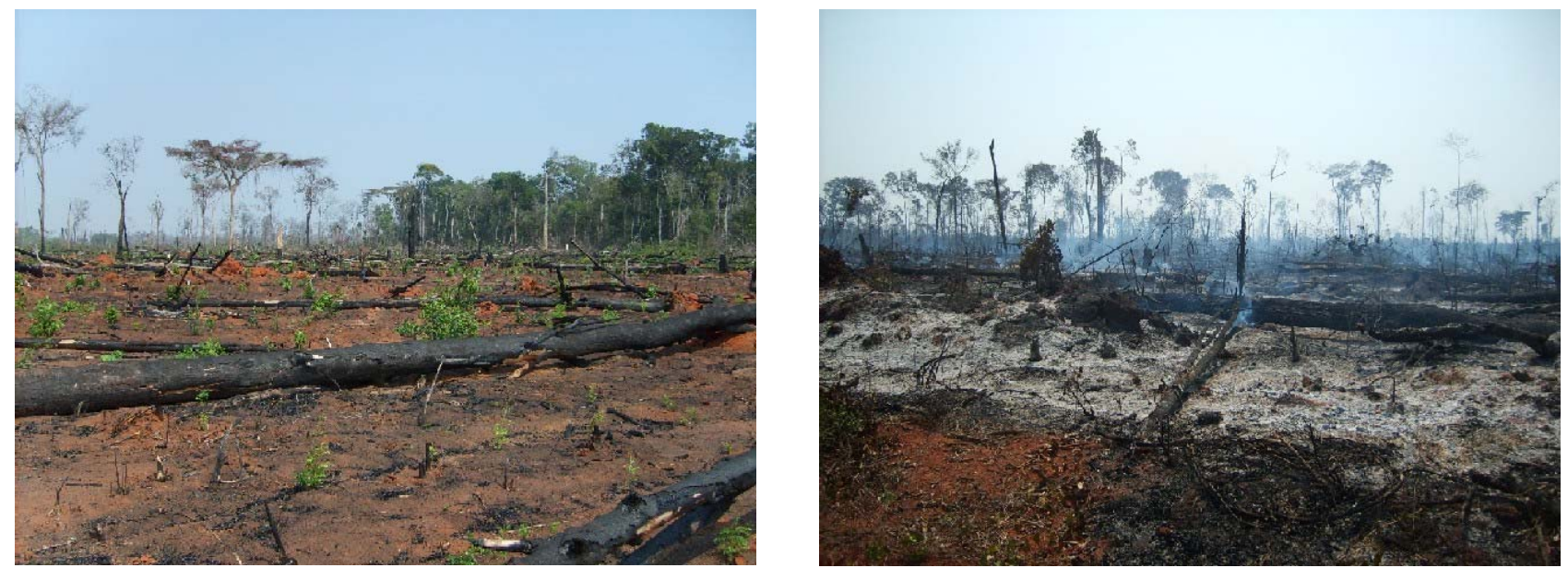

Figura 27. Prática de queimadas nas regiões de assentamento da bacia.

O processo erosivo em regiões onde a vegetação original foi substituída fica evidente em áreas onde ocorrem processos mais avançados de erosão, como a erosão em sulcos (Figura 28). A fragilidade dos solos também é evidenciada nas margens das estradas, onde a formação de canais preferenciais de escorrimento de água causa o carregamento de sedimentos e a formação de sulcos e voçorocas (Figura 29). 

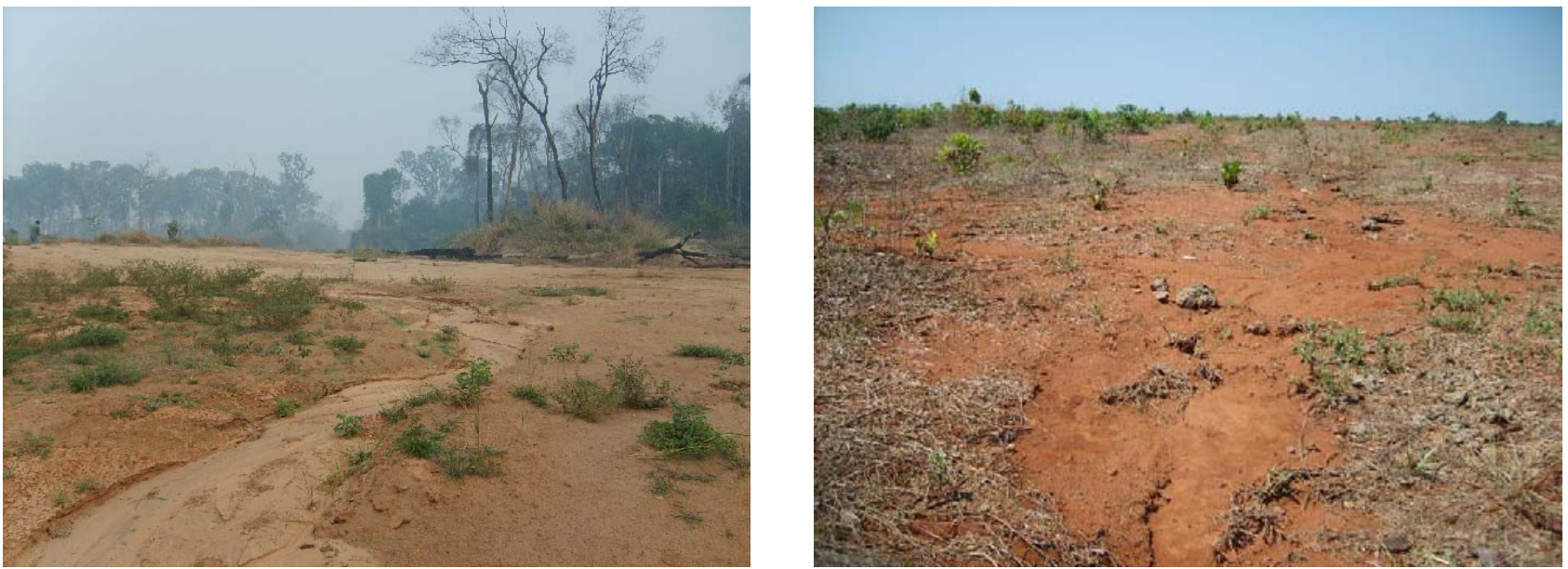

Figura 28. Áreas de ocorrência de erosão em sulco.
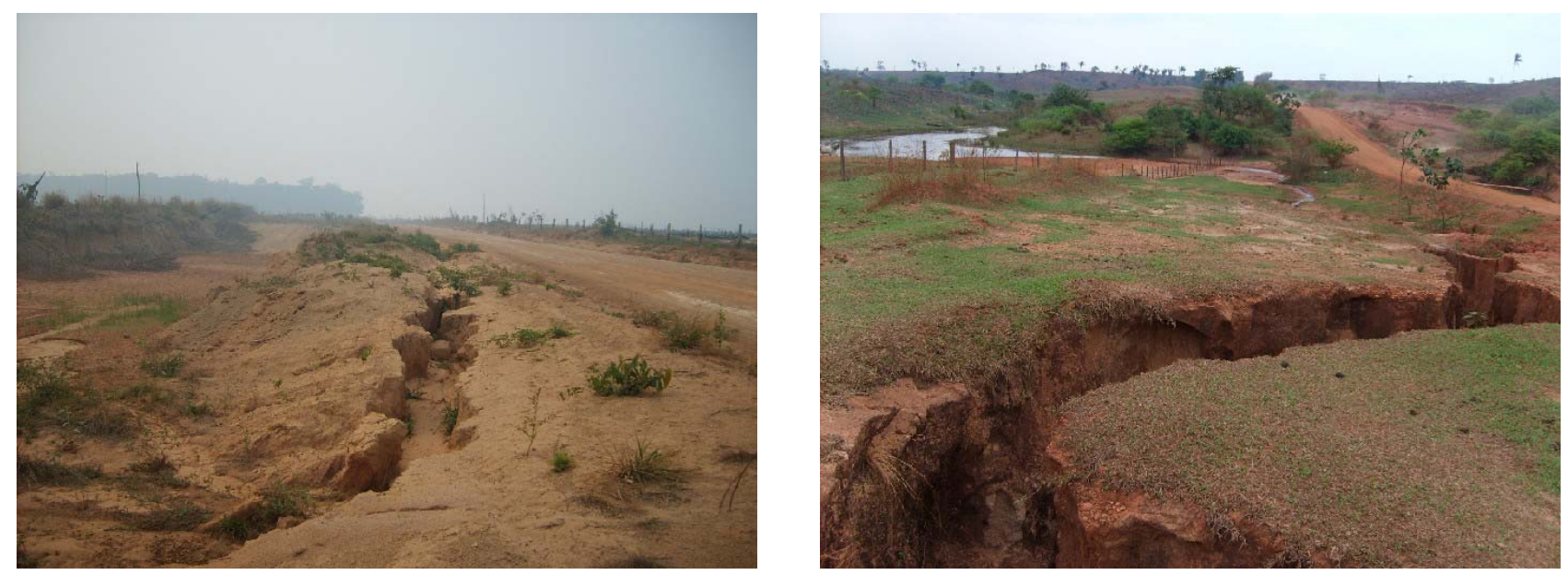

Figura 29. Áreas em estágios avançados de erosão às margens das estradas.

As vegetações que compõem as áreas de alagamento dos rios foram de forma geral preservadas, uma vez que estas são impróprias para as atividades agropecuárias. Contudo pode-se encontrar ao longo da área de estudo diversos focos de desflorestamento de matas ciliares. Outro fato preocupante é a eliminação da vegetação nativa nas áreas de nascente dos rios, que também ocorrem com grande frequiência ao longo de toda a área de estudo (Figura 30). 


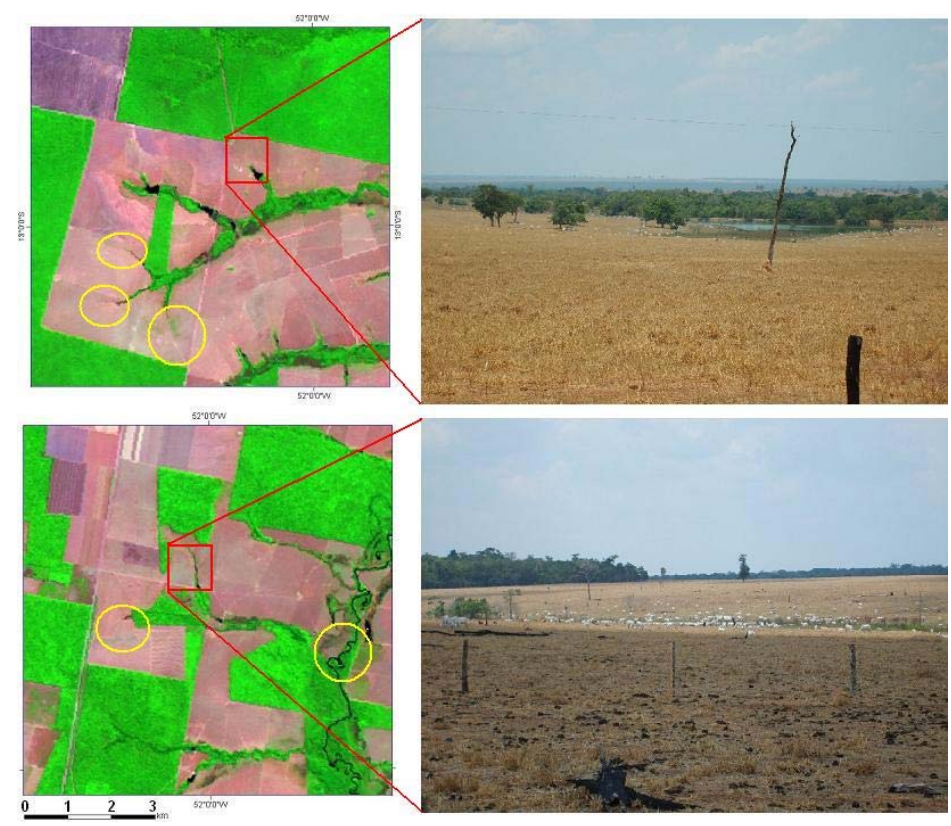

Figura 30. Áreas de nascentes de rios e matas ciliares desflorestadas.

\section{CONSIDERAÇÕES FINAIS}

O presente trabalho procurou descrever a dinâmica de ocupação na Bacia do Rio Suiá-Miçu por meio da análise do uso e cobertura da terra nos anos de 1973, 1984 e 2005. Verificou-se que a expansão das atividades agropecuárias na bacia acarretou no desflorestamento de aproximadamente $40 \%$ da vegetação original até 2005 . A criação extensiva de gado de corte e a extração madeireira foram as principais responsáveis pelo início das ocupações na região, entretanto o plantio de grãos passou a ter um importante papel nas mudanças no uso da terra a partir do ano de 2000. No último período analisado neste trabalho as plantações de culturas temporárias ocupavam $12 \%$ da bacia. As regiões fitoecológicas mais afetadas foram as Florestas Estacionais Submontanas e as Áreas de Tensão Ecológica, que tinham em 2005 apenas 54 e $42 \%$ da vegetação original respectivamente.

Sendo assim, tendo em vista a magnitude das mudanças na paisagem causadas pelas atividades humanas, é notória a necessidade de estudos mais aprofundados visando à preservação dos recursos naturais na região. A aplicação de técnicas de modelagem, por exemplo, permitiria a identificação de áreas onde os impactos decorrentes das atividades agrícolas ocorrem de forma mais intensa e, conseqüentemente onde os cuidados visando manejos mais sustentáveis deverão ser priorizados. Essa abordagem seria uma das principais ferramentas no que diz respeito à conservação dos solos e recursos hídricos, e daria suporte para ações de mitigação de impactos, como a construção de terraços para a contenção do escoamento superficial e a adoção de técnicas agrícolas menos agressivas, como o plantio direto e o cultivo mínimo.

A recuperação de áreas degradadas é outro ponto prioritário que deve ser abordado em trabalhos futuros. A recuperação da vegetação original das áreas de mananciais e de matas ciliares contribuiriam para a proteção dos recursos hídricos, evitando o despejo de sedimentos e nutrientes nos cursos d'água, assim como na manutenção dos padrões naturais do ciclo hidrológico da região.

As imagens orbitais e as técnicas de sensoriamento remoto utilizadas mostraram-se próprias e adequadas para os objetivos de analisar o processo de ocupação ocorrido na área de estudo do presente trabalho. 


\section{REFERÊNCIAS}

ALVES, D. S. Space-time dynamics of deforestation in Brazilian Amazonia. International Journal of Remote Sensing, London, v. 23, n. 14, p. 2903-2908, July 2002.

\section{BERTONI, J.; LOMBARDI NETO, F. Conservação} do solo. $5^{\text {a }}$ ed. São Paulo: Icone. 2005. 392p.

BINS, L. S.; ERTHAL, G. J.; FONSECA, L. M. G. Um método de classificação não-supervisionada por regiões. In: BRAZILIAN SYMPOSIUM ON GRAPHIC COMPUTATION AND IMAGE PROCESSING, 6., 1993, Recife. Anais..., Rio de Janeiro: Gráfica Wagner, 1993. p. 65-68.

HUETE, A.; et al. Overview of the radiometric and biophysical performance of the MODIS vegetation indices, Remote sensing of environment, New York, v. 83, p. 195-213, 2002.

Instituto Brasileiro de Geografia e Estatística (IBGE). SIDRA. Disponível em: <http:// www.sidra.ibge.gov.br/bda/tabela/ listabl.asp? $\mathrm{c}=1612 \& \mathrm{z}=\mathrm{p} \& \mathrm{o}=19 \mathrm{>}$. Acesso em: $03 \mathrm{dez}$. 2006.

INPE. Projeto PRODES: Monitoramento da Floresta Amazônica Brasileira por

Satélite, 2006. Disponível em: http:// www.obt.inpe.br/prodes/. Acesso: 29 Jan. 2007.

JUSTICE C. O.; et al. An overview of MODIS Land data processing and product status. Remote Sensing of Environment, New York, v.83, n.1-2, p.3-15, 2002.

NOBRE, C. A.; SELLERS, P. J.; SHUKLA, J. Amazonian deforestation and regional climate change. Journal of Climate, Boston, v. 4, n.10, p. 957-988, 1991.

Projeto RADAMBRASIL. Folha SC.22 Tocantins: vol. 22. Rio de Janeiro, 1981. 520p. (Levantamento de Recursos Naturais). Escala 1:1.000.000
Projeto RADAMBRASIL. Folha SD.22 Goiás: vol. 25. Rio de Janeiro, 1981. 636p. (Levantamento de Recursos Naturais). Escala 1:1.000.000

RIZZI, R.; RUDORFF, B. F. T. ; SHIMABUKURO, Y. E. Crop enhancement index based on multitemporal images: case study to detect soybean with MODIS in Brazilian Amazon. IEEE Transactions on Geoscience and Remote Sensing, New York: Institute of Electrical and Electronics Engineers, 2007.

Secretaria do Estado de Planejamento e Coordenação Geral (SEPLAN). Mapa de solos do Estado do Mato Grosso. Mato Grosso, 2001. Mapa Temático. Escala 1:250.000.

SOARES-FILHO, B. S.; et al. Modelling Conservation in the Amazon Basin. Nature. London, v. 440, n.23, p.520-523, March 2006.

TARDIN, A.T.; et al. Subprojeto desmatamento convênio IBDF/CNPq - INPE. São José dos Campos: Instituto de Pesquisas Espaciais, 1980. (INPE-1649-RPE/103). 